May 2021

\title{
Prepared to Respond? Investigating Preservice Teachers' Perceptions of their Readiness for Culturally Responsive Teaching
}

\author{
Alicia L. Moore \\ Southwestern University, moorea@southwestern.edu \\ Rebecca M. Giles \\ University of South Alabama, rgiles@southalabama.edu \\ Paige Vitulli \\ University of South Alabama, pvitulli@suthalabama.edu
}

Follow this and additional works at: https://digitalcommons.georgiasouthern.edu/ij-sotl

\section{Recommended Citation}

Moore, Alicia L.; Giles, Rebecca M.; and Vitulli, Paige (2021) "Prepared to Respond? Investigating Preservice Teachers' Perceptions of their Readiness for Culturally Responsive Teaching," International Journal for the Scholarship of Teaching and Learning: Vol. 15: No. 1, Article 10.

Available at: https://doi.org/10.20429/ijsotl.2021.150110 


\title{
Prepared to Respond? Investigating Preservice Teachers' Perceptions of their Readiness for Culturally Responsive Teaching
}

\author{
Abstract \\ Increasing cultural diversity in American schools has made preparing graduates to work with diverse \\ learners an essential goal of teacher education programs. The purpose of this study was to investigate \\ the perceptions of elementary (K-6) undergraduate preservice teachers $(n=36)$ in a dual certification \\ program regarding their personal and professional readiness for culturally responsive teaching. Data \\ collected using the Cultural Responsive Teaching Readiness Scale (Karatas \& Oral, 2017) revealed \\ relatively high mean overall with little variation $(M=4.25, S D=0.18)$ with a statistically significant \\ difference $(t(33)=18.65, p<.001)$ between Personal Readiness $(M=4.46)$ and Professional Readiness \\ $(M=3.98)$. Participants seemed to perceive classroom practice as influential in terms of their cultural \\ awareness, thus, indicating the importance of partnerships with area schools and districts to ensure \\ effective field experiences for preparing teachers for sustained employment in culturally and linguistically \\ diverse settings.

\section{Keywords} \\ Culturally Responsive Teaching, Preservice Teachers, Elementary, Teacher Educators

\section{Creative Commons License} \\ cc) (i) $\odot$
}

This work is licensed under a Creative Commons Attribution-Noncommercial-No Derivative Works 4.0 License. 
IJ-SoTL, Vol. 15 [2021], No. 1, Art. 10

\title{
Prepared to Respond? Investigating Preservice Teachers' Perceptions of their Readiness for Culturally Responsive Teaching
}

\author{
Alicia L. Moore', Rebecca M. Giles², and Paige Vitulli² \\ I. Southwestern University \\ 2. University of South Alabama
}

Received: 5 October 2020;Accepted: 9 March 202I

\begin{abstract}
Increasing cultural diversity in American schools has made preparing graduates to work with diverse learners an essential goal of teacher education programs. The purpose of this study was to investigate the perceptions of elementary (K-6) undergraduate preservice teachers $(n=36)$ in a dual certification program regarding their personal and professional readiness for culturally responsive teaching. Data collected using the Cultural Responsive Teaching Readiness Scale (Karatas \& Oral, 2017) revealed relatively high mean overall with little variation ( $M=$ $4.25, \mathrm{SD}=0.18)$ with a statistically significant difference $(\mathrm{t}(33)=18.65, \mathrm{p}<.00 \mathrm{I})$ between Personal Readiness ( $M$ $=4.46)$ and Professional Readiness $(M=3.98)$. Participants seemed to perceive classroom practice as influential in terms of their cultural awareness, thus, indicating the importance of partnerships with area schools and districts to ensure effective field experiences for preparing teachers for sustained employment in culturally and linguistically diverse settings.
\end{abstract}

\section{INTRODUCTION}

During the past ten years, research findings have shown that the nation's teaching force fails to reflect the cultural diversity represented among students (Ingersoll \& May, 20II; Ingersoll, Merrill, \& Stuckey, 20I4; King, McIntosh, \& Bell-Ellwanger, 20I6). Considering that the majority of classroom teachers and teacher candidates are White, middle-class, female, native English speakers, it is evident that many practicing and future teachers do not share the same cultural backgrounds, experiences, and values as their students (Kahn, Lindstrom, \& Murray, 20I4; Sleeter, 2008). Moreover, as novice teachers enter the classroom, they are too often provided with scripted, standardized, and uniform curricula that promote "sameness," rather than "equity" (Timberlake, Burns Thomas, \& Barrett, 2017, p. 50). Because "culture strongly influences the attitudes, values, and behaviors that students and teachers bring to the instructional process" (Gay, 2002, p. II4), preservice teachers must graduate prepared to implement culturally responsive teaching practices in order to meet the needs of all students. In this study, we investigated the culturally responsive teaching readiness of undergraduate preservice teachers in an elementary $(\mathrm{K}-6)$ dual certification program.

\section{The Need for Culturally Responsive Teaching} The Department of Education (2013) projects that $55 \%$ of the kindergarten through twelfth grade students in U. S. schools will be ethnic minorities in 2023 , with diversity increasing by an additional $6 \%$ every year to 2030 . As classrooms become more diverse, teachers need to work more effectively with students who are not part of the ethnic, racial, and cultural maority (Yoon \& Martin, 2019). Sustaining teachers in culturally and linguistically diverse schools has been a prominent issue for years (Williams, 20I6). Beginning teachers have the highest rates of turnover of any group in the profession with over $41 \%$ of new teachers leaving teaching within five years of entry (Perda, 20I3). High-poverty, high-minority, urban and rural public schools have among the highest rates of turnover, which is coupled with an annual asymmetric reshuffling of significant numbers of employed teachers from poor to not poor schools, from high-minority to low-minority schools, and from urban to suburban schools (Ingersoll, 201 I; Ingersoll \& May, 20I2). While the most frequently cited reasons for teachers departing the profession concerned dissatisfaction with any of a variety of school and working conditions, such as salaries, classroom resources, and student misbehavior (Ingersoll, Merrill, \& Stuckey, 20I4), noted trends of teachers leaving high-poverty, high-minority schools suggest cultural differences as another possibility. New teachers' lack of opportunities to develop an understanding and appreciation for cultural differences represented in their classrooms or learn how to affirm these differences through pedagogical practices may be contributing to their decision to forsake teaching in the most culturally diverse classrooms.

As the American population continues to grow in racial, ethnic, and linguistic diversity, the students in the nation's classrooms increasingly represent a wide variety of cultural backgrounds. An essential goal of teacher education programs is to ensure that graduates are prepared to work with diverse learners (Blanton, et al., 20I I; Dransfield, 20 I4; Vaz, et al., 20I5; Kent \& Giles, 2016); thus, today's teacher educators must focus their efforts on adequately preparing preservice teachers who understand the influence of culture and language on learning and who know how teaching must be designed to accommodate these influences through culturally responsive practices (Ebersole, Kanahele-Mossman \& Kawakami, 20I5).

Culturally responsive teaching (CRT) is a pedagogy that recognizes the importance of including students' cultural references in all aspects of learning. CRT affirms that all students, regardless of their gender, social class, and ethnic, racial, or cultural characteristics, should have equal access to school learning (Banks, 2010). CRT requires that teachers not only acknowledge student differences but use those differences to foster a safe and educationally prosperous environment (Gay, 20I0). "Culturally responsive pedagogy is especially pertinent to the urban context where students represent many cultures and worldviews and need support to navigate hegemonic practices they face in and out of 
school" (Stairs, 2010, p. 27). For instance, incorporating culturally relevant analogies and examples helps students visualize the course material more effectively, while at the same time bridging the gap between academic content and students' backgrounds and real-life experiences (Horowitz, Domzalski, \& Elizalde-Utnick, 20I8). Teachers who utilize culturally responsive teaching practices value students' cultural and linguistic knowledge, previous knowledge, and learning styles, viewing these factors as a way to increase academic achievement rather than as a barrier to success (Aceves \& Orosco, 2014; Gay, 2002; Siwatu, 2007). CRT is not limited to planning and delivering the best possible effective instruction but also includes the consideration of students' cultural backgrounds in order to manage the classroom effectively and utilize appropriate assessment and evaluation techniques.

\section{The Role of Teacher Preparation Programs}

Teacher preparation programs are charged with providing structured opportunities for preservice teachers to complete a rigorous preliminary phase of professional learning (Feiman-Nemser, 2003) that will equip them with the knowledge, skills, and abilities to teach students with a wide variety of needs (Cooper, Kurtts, Baber, \& Vlaeecorsa, 2008). This includes ensuring that teacher candidates are sufficiently prepared to meet the needs of culturally diverse students (Barnes, 2006; Sleeter, 2008). To reach this goal, teacher educators must consider ways to prepare preservice teachers more meaningfully to meet the needs of all students in their classrooms. Teacher education programs need to provide their teacher candidates with instruction during their coursework, field experiences, and internships regarding how to create and teach culturally responsive lessons (Yoon \& Martin, 2019). Howard (2003) asserted that teacher candidates "must critically analyze important issues such as race, ethnicity, and culture, and recognize how these important concepts shape the learning experience for many students" (p. 195).

While teacher education programs across the United States often include courses about cultural diversity and/or standards that emphasize culturally responsive teaching practices, attempts to address diversity with add-on or disjointed approaches have little success (McDonald, 2005). Instead, such efforts may result in fragmented and superficial treatments of diversity (Mills, 2008). Preservice teachers should learn about multicultural education and different aspects of diversity through experiences fully integrated into all classes and field placements in order to acquire the appropriate awareness, knowledge, and skills that support their understanding of and commitment to culturally responsive teaching.

Preservice teachers' introduction to CRT must focuses on both theory and field practice (Özüdoğru, 20I8). Increased knowledge through additional coursework alone is not enough, since field experiences in teacher education are undeniably essential (Clarke, Triggs \& Nielsen, 2014; Darling-Hammond, 2000; 2014; Gareis \& Grant, 20I4; Wilson, Floden, \& Ferrini-Mundy, 200I). A wide-range of field-based learning opportunities during their preparation program is fundamental for preservice teachers to avoid feeling underprepared to manage their classroom (Kuster, Bain, Milbrandt, \& Newton, 2010) and face the challenges of working with a diverse population of students (Kent \& Giles, 2017) when they begin teaching.

Alismail (2016) asserted that teacher preparation programs must provide sufficient training that prepares teacher candi- dates to be "critical multiculturalists" who recognize "education as a way of addressing social inequalities shaped by differences in race, ethnicity, and social class" (p. 144). Lambeth and Smith (2016) found that pre-service teachers' perceived that their skills, knowledge, and abilities concerning culturally responsive teaching improved by the end of their field experience. Krummel (20I3), who investigated various models of multicultural education in teacher preparation, found that preservice teachers are fearful of engaging in discussions about race and, therefore, need ongoing training, support, and feedback to become teachers of culturally different students. Teacher preparation programs must employ transformative preparation practices that push teacher candidates to go beyond merely articulating what they learned about cultural diversity (Taylor, Kumi-Yeboah, \& Ringlaben, 2016) and hold teacher candidates accountable for applying their knowledge by using culturally responsive practices during field experiences (Nash, 2018).

Gay and Kirkland (2003) stated that some teacher candidates may intentionally avoid developing cultural critical consciousness and self-reflection skills by averting, avoiding, or abating the value of diversity related topics. Such avoidance is aided by teacher preparation programs that do not require preservice teachers to work with diverse student populations.A study by Piper, Sharp, and Raymond (2019) noted that less than half (20 out of 57) of the teacher educators surveyed indicated that their teacher candidates completed classroom observations and field experiences in diverse school settings with some respondents raising specific concerns about how in-school experiences prepare preservice teachers for diversity in education. For example, “one respondent confided: I'm not sure our [teacher] candidates are prepared for success with student populations unlike our own local school populations. There's a sense that our institutional task is to only prepare future teachers for our community, rather than for the schools and students of the state or nation" (pg. II).

\section{SIGNIFICANCE AND PURPOSE}

Recent emphasis on teacher effectiveness and accountability has led the education policy, research, and practitioner communities to take a closer look at the effectiveness of teacher preparation programs. Several national and state studies have found new teachers to be underprepared in knowledge and skills (Kiuhara et al., 2009; Levine, 2006) related to content, pedagogy, lesson design and preparation, classroom management, and other aspects of teaching (Chesley \& Jordan, 20 I2). These findings coupled with increasing cultural diversity in American schools makes studies investigating preserve teachers' readiness for culturally responsive teaching valueable. Findings from research assessing preservice teachers' preparedness for culturally responsive teaching can serve as the impetus for effecting change making them particularly relevant to teacher educators. The purpose of this study was to investigate the personal and professional readiness for culturally responsive teaching of undergraduate preservice teachers in a dual certification program leading to recommendation for both $\mathrm{K}-6$ general and special education. The specific research questions are as follows:

\section{At what levels do K-6 preservice teach- ers perceive themselves to be personal- ly ready for culturally responsive teach- ing?}




\section{At what levels do K-6 preservice teachers perceive themselves to be professional- ly ready for culturally responsive teach- ing?}

\section{METHODS}

\section{Participants}

A quasi-experimental, survey design was used to investigate elementary preservice teachers' perceptions of their readiness for culturally responsive teaching. This study did not employ a sampling method because of low number of potential participants and a desire to reach all prospective elementary teachers at the institution. Participants were a convenience sample of 36 preservice teachers attending a public university located in an urban city in the southeastern United States. The university enrolls approximately 14,000 undergraduate and graduate students and is classified by the Southern Association of Colleges and Schools as a Level VI institution and by the Carnegie Foundation for the Advancement of Teaching as Doctoral/Research Intensive University. The participants' program (K-6 Teacher Education) is the largest in the College of Education and Professional Studies, which has approximately 2000 students. The K-6 Teacher Education program prepares participants to teach in both general and special education elementary school settings through a combination of coursework and extensive field experiences leading to a Bachelor of Science degree in Education and eligibility for teaching certification in both Elementary and Collaborative Teaching (K-6).

Demographics of participants in this study were typical of the K-6 program. All participants $(\mathrm{N}=36)$ had passed initial state testing requirements, obtained a grade point average of at least 2.75 on a 4.0 scale, and had passed a state required background check. There were 35 females and I male who were second semester juniors $(n=25)$ or first semester seniors $(n=10)$. Thirty $(83 \%)$ of the participants were White, and 30 were in the 18-24 age range. Seven (19\%) of the participants were non-traditional students, and I0 $(28 \%)$ were transfer students. Eight $(22 \%)$ of the participants were first-generation college students while 28 (78\%) participants reported one or both parents had attended college.

All demographic information was self-reported, and the categories were not operationally defined. Participation was voluntary, and there were no identified risks or benefits for the participants. There were no incentives offered for participation.

\section{Field Experience}

Field experience courses required participants to divide field hours between placements in both regular and special education elementary classroom settings. The field experience is typically scheduled for 7 hours per day with juniors completing 2 days a week (TR) and seniors completing 3 days a week (MWF) along with several full weeks (MTWRF) over the course of the semester. At the time of this study, juniors had completed approximately 100 hours of field experience, and seniors had completed approximately 150 hours of field experience.

Twenty-one (58\%) of the participants reported being placed in a suburban school for field experience. Eleven $(31 \%)$ were in urban schools, $3(8 \%)$ rural, and I (3\%) did not specify. Size of school was reported as II (3I\%) large, I 4 (39\%) medium, 8 (22\%) small, and $3(8 \%)$ did not report. Participants field placements were distributed across grade levels as follows: 3 kindergarten, 6 first, 7 second, 4 third, 9 fourth, and 7 fifth. Participants reported that their cooperating teachers had the following levels of higher education: 10 (28\%) bachelors, 20 (55\%) masters, and $6(17 \%)$ unknown. All field placements were in traditional public schools as opposed to private, charter or magnet schools, and 21 (58\%) of the participants reported attending traditional public schools as elementary students.

\section{DATA COLLECTION AND ANALYSIS}

Data were collected from junior $(n=25)$ and senior $(n=10)$ preservice teachers in a dual certification-Elementary and Special Education-program using the Cultural Responsive Teaching Readiness (CRTR) Scale developed by Karatas \& Oral (2017). The scale, which consists of 21 items, determines the culturally responsive teaching readiness level of preservice teachers along two factors: Personal Readiness and Professional Readiness. The Personal Readiness subscale consists of 12 items (I, 2, 3, 4, 5, 6, 8, $9,12,13,16$ and 17) measuring a preservice teacher's cognitive and emotional readiness as an individual with regard to enabling the learning-teaching process for students with different cultural responses and has a Cronbach's Alpha internal consistency coefficient of .92. The Professional Readiness subscale consists of 9 items $(7,10,11,14,15,18,19,20$ and 21$)$ measuring the degree of a preservice teacher's pedagogical knowledge and the level of contribution of the teacher education program in preparing preservice teachers to create a learning-teaching process for students with different cultural responses and has a Cronbach's Alpha internal consistency coefficient of .87. Cronbach's Alpha for the CRTR Scale was .90 .

Preservice teachers were asked to complete a paper and pencil version of the CRTR Scale as part of a classroom management seminar during the seventh week of a fall semester. Participants $(\mathrm{N}=36)$ responded to each item using a Likert-like scale ranging from Strongly Agree to Strongly Disagree. It took approximately 10 minutes to complete the scale, and all responses remained anonymous. Quantitative data were analyzed through both descriptive and inferential statistics using the Statistical Package for Social Sciences (SPSS).

\section{RESULTS}

Preservice teachers' mean overall scores on the Cultural Responsive Teaching Readiness were relatively high with little variation ( $M$ $=4.25, \mathrm{SD}=0.18$ ). Paired sample t-tests comparing the Personal Readiness and Professional Readiness scores reveal a statistically significant difference $(t(33)=18.65, p<.001)$. The scores for each subscale are positively correlated with one another to a statistically significant, but moderate, degree $(r=.398, p<.05)$. Internal consistency appears strong for each subscale (Cronbach Alpha Professional Readiness = .889; Cronbach Alpha for Personal Readiness $=.878$ ). As seen in Table I, Personal Readiness subscale individual items means ranged from 3.97 to 4.86 with an average score of $4.46(S D=0.63)$. Professional Readiness sub-scale individual item means, as shown in Table 2, ranged from 3.69 to 4.42 with an average score of $3.98(S D=0.83)$. Thus, the mean rating of Personal Readiness was substantially higher than the mean rating of Professional Readiness items.

Scores on each subscale were compared between genders and between white and non-white participants. There was only one male in the sample, which precluded gender comparisons being conducted.A One-Way Analysis of Variance was conducted 
Table I. Descriptive values of preservice teachers' scores on the personal readiness sub-scale

\begin{tabular}{|c|c|c|c|c|c|c|c|}
\hline Personal Readiness & SA & A & UD & D & SD & $\mathbf{M}$ & Std \\
\hline I. $\quad$ I am ready to teach in a class where there is cultural diversity. & $13(36 \%)$ & $16(44 \%)$ & $6(17 \%)$ & $(3 \%)$ & 0 & 4.14 & 0.80 \\
\hline I am curious about the cultural values of the students in my class. & $24(67 \%)$ & $12(33 \%)$ & 0 & 0 & 0 & 4.67 & 0.48 \\
\hline While I guide my students' learning, I need to consider their cultural values. & $25(69 \%)$ & II (3I\%) & 0 & 0 & 0 & 4.69 & 0.47 \\
\hline I enjoy interacting with people from different cultures. & $24(67 \%)$ & $10(28 \%)$ & $2(5 \%)$ & 0 & 0 & 4.66 & 0.94 \\
\hline $\begin{array}{l}\text { I do not tolerate students in my class to discriminate against each other because of their } \\
\text { cultural diversity. }\end{array}$ & $31(86 \%)$ & $5(14 \%)$ & 0 & 0 & 0 & 4.86 & 0.35 \\
\hline It would be enjoyable to train in a class where cultural diversity is experienced. & $19(53 \%)$ & $15(42 \%)$ & $2(5 \%)$ & 0 & 0 & 4.47 & 0.61 \\
\hline $\begin{array}{l}\text { When cultural diversity is taken into consideration, I can teach anywhere in the United } \\
\text { States. }\end{array}$ & $16(44 \%)$ & $15(42 \%)$ & $5(14 \%)$ & 0 & 0 & 4.31 & 0.71 \\
\hline $\begin{array}{l}\text { I would like to increase my interactions with non-native English speakers in and out of the } \\
\text { classroom by learning vocabulary and simple sentences in other languages }\end{array}$ & $17(47 \%)$ & $14(39 \%)$ & $5(14 \%)$ & 0 & 0 & 4.33 & 0.72 \\
\hline 12. Students should be encouraged to give examples specific to their own culture in lessons. & $13(36 \%)$ & $21(58 \%)$ & $2(\% 5)$ & 0 & 0 & 4.31 & 0.58 \\
\hline \begin{tabular}{l|l} 
13. & $\begin{array}{l}\text { Knowing how to consider students' cultural environment will increase students' academic } \\
\text { achievement. }\end{array}$
\end{tabular} & $24(67 \%)$ & $9(25 \%)$ & $\begin{array}{c}3 \\
(8 \%)\end{array}$ & 0 & 0 & 4.58 & 0.65 \\
\hline \begin{tabular}{l|l} 
16. If I have an option, I will teach in a place where people have cultural characteristics differ- \\
ent from my own culture.
\end{tabular} & $9(25 \%)$ & $18(50 \%)$ & $\begin{array}{c}8 \\
(22 \%)\end{array}$ & I (3\%) & 0 & 3.97 & 0.77 \\
\hline $\begin{array}{l}\text { 17. } \begin{array}{l}\text { Our educational system should be structured to reflect the cultural diversity from pre- } \\
\text { school to the university. }\end{array}\end{array}$ & $19(53 \%)$ & $17(47 \%)$ & 0 & 0 & 0 & 4.53 & 0.51 \\
\hline Total Personal Readiness & & & & & & 4.46 & .63 \\
\hline
\end{tabular}

to determine if there were racial differences on the mean scores for each subscale, which there were not.

There were many items on which the majority of participants (over $50 \%$ ) strongly agreed, but this occurred exclusively on items from the Personal Readiness subscale. These items include the following: Item 2- I am curious about the cultural values of the students in my class (67\%); Item 3-While I guide my students' learning, I need to consider their cultural values (69\%); Item 4- I enjoy interacting with people from different cultures (67\%); Item 5 - I do not tolerate students in my class to discriminate against each other because of their cultural diversity (86\%); Item I3Knowing how to take into account the cultural environment in which students are brought up will increase students' academic achievement (67\%); and Item I7-Our educational system should be structured to reflect the cultural diversity from pre-school to the university (53\%). The items on the Personal Readiness subscale with which the respondents expressed the highest degree of ambivalence, as evidenced by higher percentages of responses in the "undecided" category included the following: Item I- I am ready to teach in a class where there is cultural diversity (I7\% responding "undecided"), and Item I6- If I have an option, I will teach in a place where people have cultural characteristics different from my own culture (22\% responding "undecided").

In contrast to the relatively strong positive endorsement of Personal Readiness subscale items, on the Professional Readiness subscale there was a much higher incidence of items in which significant numbers of respondents answered in the "undecided," "disagree" or "strongly disagree," hence, the much lower mean score on this subscale. In examining specific items with the highest levels of affirmative endorsement in comparison to the items with the lowest level of endorsement, a pattern can be discerned. The highest endorsement of "strongly agree" for Professional Readiness came on the following items: Item I4- I gained an awareness of the cultural diversity that exists in the United States during my teacher education program. (42\% responding "strongly agree"), and Item I8- I am aware that students' cultural lives must be used as a means of achieving their learning objectives (44\% responding "strongly agree"). While this reflects a much lower degree of affirmative responding to Professional Readiness items as opposed to Personal Readiness, also notable is that over $50 \%$ of respondents responded to all the Professional Readiness items by endorsing "strongly agree" or "agree." On average, respondents endorsed "strongly agree" or "agree" $73 \%$ of the time on the Professional Readiness items. In other words, while respondents reported less affinity overall for Professional Readiness items than they did for Personal Readiness items, they still exhibited a strong positive belief in items on both subscales.

Items that were the least positively endorsed on the Professional Readiness subscale included the following: Item 7- My instructors created awareness of the cultural diversity in the United States during my teacher preparation program, Item I II find my undergraduate education program sufficient in creating awareness about cultural diversity in the United States, Item

\begin{tabular}{|c|c|c|c|c|c|c|c|c|}
\hline \multicolumn{2}{|c|}{ Professional Readiness } & SA & $\mathbf{A}$ & UD & D & SD & $\mathbf{M}$ & Std \\
\hline 7. & $\begin{array}{l}\text { My instructors created awareness of the cultural diversity in the United States during } \\
\text { my teacher preparation program. }\end{array}$ & $8(22 \%)$ & $16(44 \%)$ & $9(25 \%)$ & $3(12 \%)$ & 0 & 3.81 & 0.89 \\
\hline 10. & My required courses I have taken have contributed to my sensitivity to cultural values. & $12(33 \%)$ & $16(44 \%)$ & $4(1 \mid \%)$ & $3(12 \%)$ & 0 & 4.06 & 0.91 \\
\hline II. & $\begin{array}{l}\text { I find my undergraduate education program sufficient in creating awareness about cul- } \\
\text { tural diversity in the United States. }\end{array}$ & $822 \%)$ & $17(47 \%)$ & $9(25 \%)$ & $2(5 \%)$ & 0 & 3.86 & 0.83 \\
\hline 14. & $\begin{array}{l}\text { I gained an awareness of the cultural diversity that exists in the United States during } \\
\text { my teacher education program. }\end{array}$ & 15 (42\%) & $13(36 \%)$ & 6 (17\%) & 2 (5\%) & 0 & 4.14 & 0.90 \\
\hline 15. & $\begin{array}{l}\text { I obtained information about different cultures in the United States during my teacher } \\
\text { education program. }\end{array}$ & $822 \%)$ & $19(53 \%)$ & $6(17 \%)$ & 3 (12\%) & 0 & 3.89 & 0.85 \\
\hline 18. & $\begin{array}{l}\text { I am aware that students' cultural lives must be used as a means of achieving their } \\
\text { learning objectives. }\end{array}$ & $16(44 \%)$ & $19(53 \%)$ & I (3\%) & 0 & 0 & 4.42 & 0.55 \\
\hline 19. & $\begin{array}{l}\text { Materials and activities used in my teacher education courses were sufficient in terms } \\
\text { of presenting information related to cultural diversity. }\end{array}$ & 8 (22\%) & $13(36 \%)$ & II (30\%) & 4 (II\%) & 0 & 3.69 & 0.95 \\
\hline 20. & $\begin{array}{l}\text { The elective courses I have taken in my teacher education program have contributed } \\
\text { to my sensitivity to cultural values. }\end{array}$ & II (30\%) & 14 (39\%) & $10(28 \%)$ & I (3\%) & 0 & 3.97 & 0.84 \\
\hline 21. & $\begin{array}{l}\text { I have gained awareness of cultural diversity as a result of our instructors' personal } \\
\text { lives and experiences. }\end{array}$ & $9(25 \%)$ & 17 (47\%) & 10 (28\%) & 0 & 0 & 3.97 & 0.74 \\
\hline \multicolumn{2}{|c|}{ Total Professional Readiness } & & & & & & 3.98 & 0.83 \\
\hline
\end{tabular}


15- I obtained information about different cultures in the United States during my teacher education program, and Item 19- Materials and activities used in my teacher education courses were sufficient in terms of presenting information related to cultural diversity. Only $22 \%$ of the participants strongly agreed with these four items. This suggests that respondents had particularly negative beliefs about the curriculum in their teacher preparation programs and the degree to which it prepared them to serve as a multicultural educator.

\section{DISCUSSION}

In this study, preservice teachers' Cultural Responsive Teaching Readiness mean total scores $(M=4.25, S D=0.18)$ were substantially higher than total mean scores $(M=3.63, S D=.9)$ reported by Ozudogru (2018) in his study of 403 Turkish preservice teachers indicating that teacher educators in the United States as represented by those at the institution where this study was conducted, are at least attempting to provide preservice teachers with culturally responsive teaching and learning strategies. Specifically, a vast majority $(72 \%)$ of participants in this study strongly agreed (25\%) or agreed $(47 \%)$ that they gained awareness of cultural diversity as a result of their instructors' personal lives and experiences seeming to eliminate this particular institution from the claim by Hayes and Juárez (20I2) that White racial domination still occurs in teacher education, thus, impeding the preparation of teachers for culturally responsive teaching. Further, respondents exhibited positive beliefs on items related to both their personal and professional readiness to teach culturally diverse learners, which is consistent with the findings of other studies (Pohan \& Aguilar, 200 I; Kahn, et al., 20 I4), while also indicating the need for additional opportunities to develop professional readiness within this teacher preparation program.

Kahn et. al (20l4) states that teacher education programs need to provide preservice teachers with opportunities to develop cultural competence through a variety of personal, professional, and educational experiences. Although not specifically asked, responses of preservice teachers in this study seemed to denote the importance of field experiences. For example, a majority of participants (53\%) strongly agreed that "It would be enjoyable to train in a class where cultural diversity is experienced" (Item 6) Further, a high percentage of respondents agreed that they gained an awareness of cultural diversity during their teacher education program (Item 14) while disagreeing that instructors created awareness of the cultural diversity (Item 7) and that materials and activities used in teacher education courses were sufficient in terms of presenting information related to cultural diversity (Item 19). These responses indicate that participants perceived classroom practice as influential in terms of their cultural awareness. Similarly, Lambeth and Smith (2016) found that much of the preservice teachers' knowledge about teaching students of other races and socioeconomic backgrounds emerged either as a result of implementing a variety of activities and strategies for assessing the impact on students during field placements and internship or from the guidance and recommendations provided by mentor teachers. These findings seem to indicate that preparing teachers for sustained employment in culturally and linguistically diverse schools might best be accomplished in partnership with area schools and districts. As noted by Yoon and Martin (2019), once preservice teachers have graduated and become inservice teachers, they will need curriculum, culturally respon- sive teaching professional development, and sustained support as they continue to learn to approach instruction from a culturally responsive perspective.

\section{LIMITATIONS}

There were certain limitations in this study that should be acknowledged. First, the generalizability of the findings is limited as a result of using a fairly homogenous, convenience sample of elementary preservice teachers from a single university. The small sample size also limits the ability to apply findings to a larger population. Additionally, the limitations of collecting data using self-report instruments have been noted (Sallis \& Saelens, 2000). Even though anonymity was maintained, participants' responses could reflect their desire to present a favorable image of themselves. This tendency, known as socially desirable reporting, could obscure the relationships between variables (van de Mortel, 2008).

\section{FURTHER RESEARCH}

To obtain a more complete picture of preservice teachers personal and professional readiness for culturally responsive teaching, it is recommended that similar studies be conducted with a larger sample of diverse participants preparing to teach at various levels. Assessing preservice teachers' readiness for culturally responsive teaching at various points in their program would also be beneficial to identify factors that most significantly contribute to their readiness. Future research studies should explore the specific teaching practices used and taught within teacher education programs' methods courses and assess how these experiences impact preservice teachers' knowledge and abilities, possibly using focus groups to further explore survey results. As Clift (2008) argues, "There is little data to provide links between an individual's knowledge, their learning within a teacher education program, their actual teaching in schools, and their students' learning" ( $p$. 828). Further research connecting preservice teachers' awareness of culturally responsive teaching practices and their implementation of such practices both during field experiences and as novice professionals is needed.

\section{CONCLUSIONS}

It is vital for teachers to be positive and confident that they can facilitate success for their students (Beacham \& Rouse, 20I2). Despite efforts aimed at increasing knowledge of diversity, helping teachers become culturally responsive continues to challenge teacher educators today (Ladson-Billings, 20 I I). Akiba (20 I I) cited field experiences for understanding diverse students as a necessary component of teacher education programs, and research (Beaudry, 2015: Lambeth \& Smith, 2016) has found that preservice teachers perceive field experience working with students of non-Caucasian races and cultures to improve their skills, knowledge, and abilities concerning culturally responsive teaching. Further, professional development based on cultural theory and research was found to support experienced teachers in creating culturally responsive classrooms (Trumbull et al., 2020). Thus, teacher preparation programs should reexamine their course curriculum and program goals to ensure preservice teachers are being adequately equipped for culturally responsive teaching (Miller \& Mikulec, 20I4) while also providing the field experiences necessary to make personal connections required to move knowledge and skills beyond the realm of theoretical and intangible by providing a context to authentically examine crit- 
ical cultural issues. This study contributes to a growing body of research regarding the importance of preparing preservice teachers to help all students, regardless of cultural influences, reach their highest potential. Preparing future teachers to be culturally responsive to the needs of their students is a tremendous responsibility and one that falls to all teacher educators. As the results of this study demonstrate, teacher educators must carefully evaluate how their respective programs prepare preservice teachers to address diversity both personally and professionally. To be successful in preparing future teachers for diverse classrooms, teacher educators must collaborate with colleagues across departments and programs to investigate preparation practices used during coursework as well as during field experiences and identify areas where improvements can be made.

\section{REFERENCES}

Akiba, M. (20I I). Identifying program characteristics for preparing pre-service teachers for diversity. Teachers College Record, I I 3(3), 658-697.

Alismail, A. H. (20I6). Multicultural education:Teachers' perceptions and preparation. Journal of Education and Practice, 7(I I), |39-| 46.

Banks, J.A. (20I0). Multicultural education: Characteristics and goals. In J.A. Banks \& C.A. M. Banks, (Eds.). Multicultural education: Issues and perspectives (7th Ed.) Pp. 3-3I). USA: John Wiley \& Sons.

Beacham, N., \& Rouse, M. (20I2). Student teachers' attitudes and beliefs about inclusion and inclusive practice. Journal of Research in Special Needs, I2(I), 3-I I.

Beaudry, C. (20I5). Community connections: Integrating community-based field experiences to support teacher education for diversity. Educational Considerations, 43(I), 29-35.

Blanton, L. P., Pugach, M. C., \& Florian, L. (20I I). Preparing general education teachers to improve outcomes for students with disabilities. American association of colleges for teacher education, 20005.

Chesley, G., \& Jordan, J. (20I2). What's missing from teacher prep? Educational Leadership, 69(8), 4I-45. Washington, DC: Association for Supervision \& Curriculum Development. http://eric.ed.gov/?id=EJ9

Clarke,A., Triggs, V., \& Nielsen,W. (20I4). Cooperating teacher participation in teacher education:A review of the literature. Review of Educational Research, 84(2), 163-202.

Clift, R.T. (2008). Rethinking the study of learning to teach. In M. Cochran-Smith, S. FeimanNemser, D. J. Mclntyre \& K. E. Demers (Eds.), Handbook of research on teacher education (827-834). New York, NY: Routledge.

Coffey, H. (2010). "They taught me:” The benefits of early community-based field experiences in teacher education. Teaching and Teacher Education:An International Journal of Research and Studies, 26(2), 335-342.

Cooper, J. E., Kurtts, S., Baber, C. R., \& Vallecorsa, A. (2008). A model for examining teacher preparation curricula for inclusion. Teacher Education Quarterly, 35(4), I55- I 76.

Creswell, J.W. (20I3). Research Design: Qualitative, Quantitative, and Mixed Methods Approaches (4th ed). Thousand Oaks, CA: Sage.
Darling-Hammond, L. (2000). Reforming teacher preparation and licensing: Debating the evidence. Teachers College Record, I02(I), 28-56.

Darling-Hammond, L. (20I4). Strengthening clinical preparation: The Holy Grail of teacher education. Peabody Journal of Education, 89(4), 547-56I.

Dransfield, D. (2014). The effect of a single introductory special education course on the attitudes of prospective teachers toward inclusion (Doctoral dissertation). Kent, $\mathrm{OH}$ : Kent State University. Retrieved from https://etd.ohiolink. edu/!etd.send_file?accession=kent l 396354646\&disposition=inline

Ebersole, M., Kanahele-Mossman, H. \& Kawakami, A. (20I5). Culturally responsive teaching: Examining teachers' understandings and perspectives. Journal of Education and Training Studies, 4(2), 97- 104.

Gareis, C. R., \& Grant, L.W., (2014), The efficacy of training cooperating teachers. Teaching and Teacher Education, 39, 77-88.

Gay, G. (2002). Preparing for culturally responsive teaching. Journal of Teacher Education, 53, 106-1 I6.

Gay, G., \& Kirkland, K. (2003). Developing cultural critical consciousness and self-reflection in preservice teacher education. Theory into Practice, 42(3), I8I-187.

Feiman-Nemser, S. (2003).What new teachers need to learn? Educational Leadership, 60(8), 25-29.

Hayes, C., \& Juárez, B. (20I2). There is no culturally responsive teaching spoken here:A critical race perspective. Democracy \& Education, 20(I), I- I4.

Horowitz, G., Domzalski, A. C., \& Elizalde-Utnick, G. (2018). Can we teach science in a more culturally responsive way without sacrificing time or content? Journal of College Science Teaching, 47(6), 8- I0.

Ingersoll, R. (20I I). Do we produce enough mathematics and science teachers? Phi Delta Kappan, 92(6) 37-4I.

Ingersoll, R., \& May, H. (20I2). The magnitude, destinations and determinants of mathematics and science teacher turnover. Educational Evaluation and Policy Analysis, 34(4), 435-464.

Ingersoll, R., Merrill, L., \& Stuckey, D. (20I4). Seven Trends:The Transformation of the Teaching Force. Updated April 2014. CPRE Report. \#RR-80. Consortium for Policy Research in Education. Consortium for Policy Research in Education. Retrieved from https://files.eric.ed.gov/fulltext/ED566879. pdf

Kahn, L. G., Lindstrom, L. \& Murray, C. (20।4). Factors contributing to preservice teachers' beliefs about diversity. Teacher Education Quarterly, 53-70.

Karataș, K., \& Oral, B. (20I7). Cultural responsive teaching readiness scale validity and reliability study. Journal of Educational Sciences Research, 7(2), 245-256

Kent, A. M., \& Giles, R. M. (2016). Dual certification in general and special education:What is the role of field experience in preservice teacher preparation? The Professional Educator, 40(2).

Kiuhara, S.A., Graham, S., \& Hawken, L. S. (2009). Teaching writing to high school students: A national survey. Journal of Educational Psychology I0I(I), I36-160. http://eric.ed.gov l?id=EJ829242

King, J. B., Mclntosh, A. \& Bell-Ellwanger, J. (20I6). The State of Diversity in the Educator Workforce. Washington, DC: U.S. De- 
partment of Education, Office of Planning, Evaluation and Policy Development, Policy and Program Studies Service.

Kuster, D., Bain, C, Milbrandt, M., \& Newton, C. (2010). Novice art teachers: Navigating through the first year. Visual Arts Research, 36, 22-30.

Krummel,A. (20I3). Multicultural teaching models to educate pre-service teachers: Reflections, service-learning, and mentoring. Current Issues in Education, I6(I), I-8.

Ladson-Billings, G. J. (20I I). Is meeting the diverse needs of all students possible? Delta Pi Record, 48(I), I3-15. http://dx. doi.org/I0.1080/00228958.20II.105167I6

Lambeth, D.T., \& Smith, A. M. (2016). Pre-service teachers' perceptions of culturally responsive teacher preparation. Journal of Negro Education, 85( I ), 46-58. https://doi-org.libproxy. usouthal.edu/ $10.7709 /$ jnegroeducation.85.I.0046

Levine, A. (2006). Educating school teachers. Washington, DC: Education Schools Project. Teachersadvance2.qxd (edschools. org)

McDonald, M.A. (2005). The integration of social justice in teacher education: Dimensions of prospective teachers' opportunities to learn. Journal of Teacher Education, 56(5): 4l8-435.

Miller, P. C., \& Mikulec, E.A. (20I4). Pre-service teachers confronting issues of diversity through a radical field experience. Multicultural Education, 2I (2), I8-24.

Mills, C. (2008). Making a difference: moving beyond the superficial treatment of diversity. Asia-Pacific Journal of Teacher Education, 36(4), 26I-275. http://dx.doi. org/ $10.1080 / 13598660802375925$

Özüdoğru, F. (20I8). The readiness of prospective teachers for culturally responsive teaching. Acta Didactica Napocensia, I I (3-4), I-I 2.

Perda, D. (20I3). Transitions into and out of teaching:A longitudinal analysis of early career teacher turnover (Unpublished doctoral dissertation). University of Pennsylvania, Philadelphia.

Piper, R. E., Sharp, L.A., \& Raymond, R. D. (2019). Diversity in literacy education: How are literacy teacher educators preparing teacher candidates? Georgia Journal of Reading, 42(I), 6-17.
Pohan, C., \& Aguilar,T. (200I). Measuring educators' beliefs about diversity in personal and professional contexts. American Educational Research Journal, 38(I), I59-I82.

Sallis, J. F., \& Saelens, B. E. (2000). Assessment of physical activity by self-report: Status, limitations, and future directions. Research Quarterly for Exercise and Sport, 7 I (2), I- I 4.

Sleeter, C. E. (2008). Preparing white teachers for diverse students. In M. Cochran-Smith, S. Feiman-Nemser, \& D. J. McIntyre (Eds.), Handbook of research on teacher education: Enduring questions in changing contexts (3rd ed., pp. 559-582). New York: Routledge and Association of Teacher Educators.

Stairs, A. J. (20I0). The learning and practice of preservice teachers in an urban school-university partnership:The struggle to enact culturally responsive pedagogy. 2010 Yearbook of Urban Learning, Teaching, and Research. 26-36.

Taylor, R., Kumi-Yeboah,A., \& Ringlaben, R. P. (20I6). Pre-service teachers' perceptions towards multicultural education \& teaching of culturally \& linguistically diverse learners. Multicultural Education, 23(3-4), 42-48.

Timberlake, MT, Burns Thomas, A, Barrett, B (2017) The allure of simplicity: Scripted curricula and equity. Teaching and Teacher Education, 67, 46-52.

Trumbull, E., Greenfield, P. M., Rothstein-Fisch, C., Maynard,A. E., Quiroz, B., \& Yuan, Q. (2020). From Altered Perceptions to Altered Practice:Teachers Bridge Cultures in the Classroom. School Community Journal, 30(I), 243-266.

van de Mortel,T. F. (2008). Faking it: Social desirability response bias in self-report research. The Australian Journal of Nursing, 25(4), 40-48.

Wilson, S., Floden, R., \& Ferrini-Mundy, J. (200I). Teacher preparation research: Current knowledge, gaps, and recommendations. Center for the Study of Teaching and Policy, University of Washington. Retrieved from http://www.education. uw.edu/ctp/sites/default/files/ctpmail/PDFs/TPExecSummary-03-200I.pdf

Yoon, J., \& Martin, L.A. (2019). Infusing culturally responsive science curriculum into early childhood teacher preparation. Research in Science Education, 49(3), 697-7I0. 